\title{
UPDATE ON LYMPHOMA PATHOLOGY: II THE ROLE OF GENETIC MUTATIONS IN THE PATHOGENESIS OF LYMPHOID NEOPLASIA
}

\author{
RW Blewitt, Consultant Pathologist \\ Lancaster and Kendal Hospitals
}

\section{INTRODUCTION}

In a sense we know the cause of cancer; it is genetic mutations ${ }^{(1,2)}$. These operate by progressively damaging the mechanisms for control of the cell mitotic cycle. For mutations to do this several conditions must apply:

- the mutations must somehow escape the cell's DNA repair mechanisms

- the mutant cell must be able to enter the mitotic cycle by evading normal mechanisms which prevent this

- the mutant cell must survive the effects of the mutation and be able to pass on its defective DNA to succeeding generations of its progeny.

When sufficient mutations have accumulated in its mitotic control genes, a cell can break free of mitotic control and become a cancer cell.

\section{MUTATIONS}

(a) What is a mutation? ${ }^{(3)}$

Human body cells, apart from red blood cells and germ cells, contain in their nuclei 50,000 genes encoded within DNA molecules comprising $6 \times 10^{9}$ base pairs, and packaged into two sets of 23 chromosomes. A mutation is a change in the DNA molecule, and we refer in this paper to permanent changes, uncorrected by DNA repair mechanisms. Mutations range from a change in a single base-pair of DNA to loss or duplication of an entire chromosome (Figure 1).

Translocations are found particularly commonly in lymphoid neoplasms ${ }^{(1)}$ (Figure 2).

Figure 2 shows the common translocation in Burkitt's lymphoma in which the growth promoting gene c-myc is

\begin{tabular}{|c|c|}
\hline \multicolumn{2}{|c|}{ CHROMOSOME NUMBER } \\
\hline $\begin{array}{l}\text { Triploidy }(3 N)^{*} \\
\text { Aneuploidy }\end{array}$ & $\begin{array}{l}\text { in } 2 \% \text { spontaneous abortions } \\
\text { eg Down's Syndrome }(\mathrm{N}=47)\end{array}$ \\
\hline \multicolumn{2}{|c|}{ STRUCTURAL CHROMOSOME ABNORMALITIES } \\
\hline Translocations & $\begin{array}{l}\text { Swap of segment of DNA between } \\
\text { chromosomes }\end{array}$ \\
\hline Deletions & loss of a segment of DNA \\
\hline Duplications & doubled segment of DNA \\
\hline Inversion & DNA segment reversed after repair \\
\hline \multicolumn{2}{|c|}{ POINT MUTATION } \\
\hline \multicolumn{2}{|c|}{ Change of a single DNA base-pair } \\
\hline
\end{tabular}

Figure 1 Common types of genetic mutation $(* N=$ number of chromosomes $)$

placed next to the immunoglobulin heavy chain gene on chromosome 14 and thereby activated.

\section{(b) Causes of mutation}

The vast majority of mutations can be regarded as rare random errors in the complicated process of DNA replication, with a minor contribution from background radiation, chemicals, and free radicals. Most mutations, therefore, occur spontaneously during mitoses or meiosis. Conditions of chronic lymphocyte proliferation such as Helicobacter infection of the stomach, or Hashimoto's thyroiditis are associated with an increased incidence of lymphoma.

\section{(c) Rate of mutation}

The "normal" mutation rate in human cells is difficult to estimate, but evidence from the incidence of new cases of dominant mutations (such as Huntington's Chorea), in vitro cell culture, and studies on the rare eye tumour, retinoblastoma, suggest a figure of about one mutation per gene per mitosis per 10 million cells ${ }^{(4)}$. Is that enough to cause cancer? We shall shortly see that it is. Furthermore there is evidence

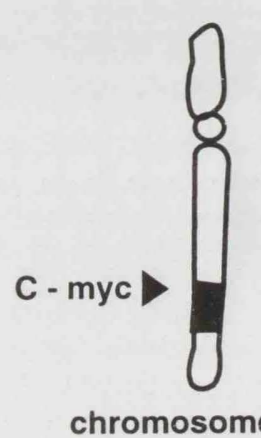

8

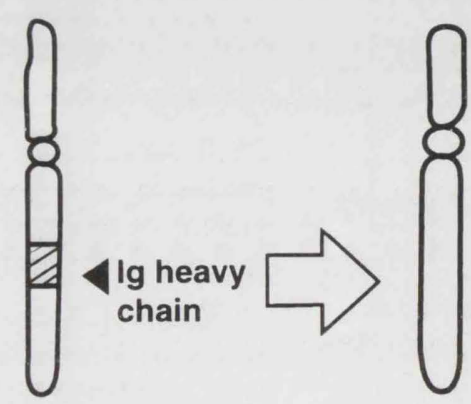

chromosome chromosome

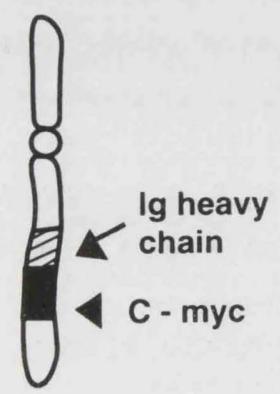

14

Figure 2 Translocation of c-myc gene from chromosome 8 to 14 
that the mutation rate is not constant but increases with age, perhaps exponentially ${ }^{(5)}$.

\section{(d) Consequences of mutation}

Whatever the cause of the mutation, the result with respect to a particular gene will be one of the following:

- no effect

- inactivation of the gene

- inappropriate activation of the gene.

Inappropriate activation of a gene is frequently seen as a result of translocations in lymphoid neoplasia.

(e) How many mutations are needed to produce a cancer? Most human cancers contain multiple mutations. The number of mutations and the genes responsible are under intensive investigation, but analysis of age-specific incidence curves (see Part I) has suggested as many as seven mutations, and certainly more than one ${ }^{(6)}$.

(f) A mathematical digression into acute lymphoblastic leukaemia

One can get quite a good idea of the number of mutations required to produce acute lymphoblastic leukaemia by the study of data (Figure 3). The incidence of acute lymphoblastic leukaemia is $1 / 100,000 /$ year and it is estimated that there are $10^{13}$ lymphocyte divisions per year in a child ${ }^{(7)}$. Mutation rate per gene per cell division is about $10^{-7}$.

The probability of two independent events each of probability $\mathrm{p}$ is $\mathrm{p} \mathrm{x} \mathrm{p}$, and of $\mathrm{n}$ independent events, $\mathrm{p}^{\mathrm{n}}$.

\begin{tabular}{|l|l|l|}
\hline $\begin{array}{l}\text { Mutation at } n \\
\text { specified sites }\end{array}$ & $\begin{array}{l}\text { Probability (risk) } \\
\text { per year per person }\end{array}$ & $\begin{array}{l}\text { Predicted Occurrence } \\
\text { per 100,000 people } \\
\text { ie. incidence rate }\end{array}$ \\
\hline$n=1$ & $10^{13} \times 10^{-7}=10^{6}$ & $10^{11}$ \\
$n=2$ & $10^{13} \times\left(10^{-7}\right)^{2}=10^{-1}$ & 10,000 \\
$n=3$ & $10^{13} \times\left(10^{-7}\right)^{3}=10^{-8}$ & 0.001 \\
$n=4$ & $10^{13} \times\left(10^{-7}\right)^{4}=10^{-15}$ & $10^{-10}$ \\
\hline
\end{tabular}

Figure 3 Predicted incidence rates of acute lymphoblastic leukaemia from models using one to four mutations

(g) Conclusions from mathematical models of acute lymphoblastic leukaemia

Spontaneous mutation rate is sufficient by itself to generate the observed numbers of acute lymphoblastic leukaemia. If only one mutation were required then everybody would die of the disease. The observed rate places the numbers of mutations in the range two to three.

\section{CELL CYCLE CONTROL ${ }^{(8)}$}

Before considering specific types of mutation found in lymphoid neoplasia we need to understand the basics of cell cycle control (Figure 4).

\section{(a) Phases of the cell cycle}

After mitosis (M phase) the cell enters a period of rest (gap 1 or G1 phase) and cannot proceed further until the cycle control "gate" is opened by transcription factor. When permitted to do so, the cell enters the $\mathrm{S}$ or synthesis phase when DNA is replicated. This is followed by gap 2 (G2 phase) and mitosis again.

\section{(b) Purpose of cycle control gate}

Often termed the G1 checkpoint, this is the point at which mitotic restraint is applied. There are two essential purposes

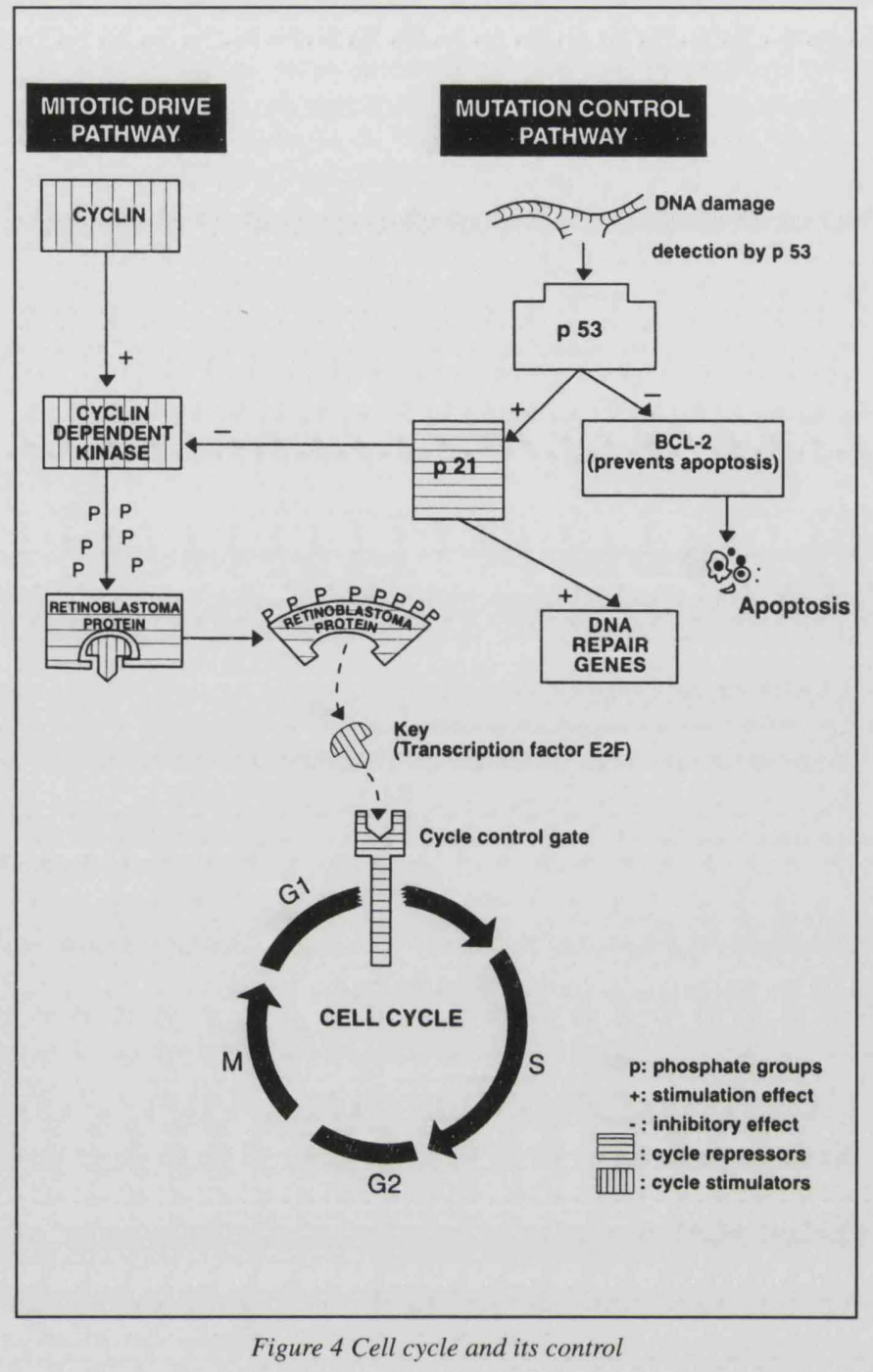

of cell cycle control, the first one obvious, the second only recently appreciated:

i to control the rate of cell proliferation

ii to stop mutated cells from cycling.

\section{(c) Overview of control system}

Proximal to the control gate the system consists of a sequence of stimulatory and inhibitory proteins, forming a "cascade" not unlike that of blood coagulation but allowing integration of signals rather than amplification. The system has two arms, a stimulatory mitotic drive pathway and a mutation control pathway which is inhibitory. If the inhibitory signals are preponderant then the control gate is not opened and the cell gets stuck in G1 (G1-arrest).

In reality the system is a good deal more complex than in Figure 4. There are, for instance, multiple types of cyclin and several more steps in the pathways. DNA repair encompasses several different systems requiring many genes. All these numerous control and repair genes are potential targets for random mutation.

\section{(d) Mitotic drive}

The driving force for mitosis is provided by the protein cyclin which fluctuates throughout the cycle and when high activates its partner enzyme cyclin-dependent kinase. The enzyme phosphorylates retinoblastoma protein. Retinoblastoma is a cycle suppressor which binds to the gate control key (E2F). When sufficiently phosphorylated, the retinoblastoma protein changes shape and releases the key.

(e) Mitotic inhibition by the mutation control pathway Protein 53 (p53) is the central part of the mutation control 
system ${ }^{(9)}$ and has been termed "the guardian of the genome". It is the most commonly mutated gene found in human cancers. P53 is able to detect DNA damage and responds by stimulating the production of p21 (a signalling protein) and inhibiting BCL-2 (apoptosis suppressor). P21 then inhibits cyclin-dependent kinase, which will cause the cell to undergo a G1 arrest; meanwhile p21 calls the DNA repair system into action.

\section{(f) Consequences of G1 arrest of a mutant cell}

A cell in which DNA damage has been detected will be held in G1 arrest, potentially for a prolonged period, until DNA repair is completed.

If DNA repair cannot be achieved, there is no way out of G1 arrest and the cell is destroyed by apoptosis.

\section{(g) Apoptosis}

Apoptosis is a programmed self-destruct mechanism which is built into every cell, but normally suppressed by the protein BCL-2 $2^{(10)}$. When p53 inhibits BCL-2, the cell is free to commit suicide. It is somewhat sobering to realise that all our cells are primed and ready to self-destruct and only continue to live in the presence of a specific signal. The system has evolved to fail safe. BCL-2 gene is mutated in many forms of cancer, including follicular lymphoma

\section{MUTATIONS FOUND IN LYMPHOID NEOPLASIA}

\section{(a) Introduction}

Many different mutations have been recorded in the various types of lymphoid neoplasm ${ }^{(11)}$, but several are found with a high degree of consistency ${ }^{(12)}$ (Figure 5). These are mostly translocations. Lymphocytes are especially vulnerable to translocation errors because of their unique method of generating antigenic specificity ${ }^{(1)}$. Immunoglobulin genes are rearranged by a randomized process of DNA cutting, translocation and joining ${ }^{(13)}$.

\begin{tabular}{|c|c|c|c|}
\hline Tumour Type & Mutation & Frequency & Result \\
\hline Follicular lymphoma ${ }^{(14)}$ & Translocation 14;18 & $90 \%$ & $\begin{array}{l}\mathrm{BCL}-2 \\
\text { activation }\end{array}$ \\
\hline $\begin{array}{l}\text { Mantle cell } \\
\quad \text { Iymphoma }^{(15)}\end{array}$ & Translocation 11;14 & $70 \%$ & $\begin{array}{l}\text { increased } \\
\text { CYCLIN D1 }\end{array}$ \\
\hline Burkitt's lymphoma ${ }^{(16)}$ & Translocation 8;14 & $80 \%$ & $\begin{array}{l}\text { C-MYC } \\
\text { activation }\end{array}$ \\
\hline $\begin{array}{l}\text { Anaplastic large cell } \\
\text { lymphoma }\end{array}$ & Translocation 2;5 & $60 \%$ & $\begin{array}{l}\text { p80 activation } \\
\text { (function } \\
\text { unknown) }\end{array}$ \\
\hline $\begin{array}{l}\text { High-grade } \\
\text { transformation of } \\
\text { low-grade B cell } \\
\text { lymphoma }{ }^{(18)}\end{array}$ & p53 & $\begin{array}{l}20 \% \text { of } \\
\text { high-grade } \\
\text { B-cell } \\
\text { lymphoma }\end{array}$ & $\begin{array}{l}\text { inactivation } \\
\text { of } p 53\end{array}$ \\
\hline
\end{tabular}

Figure 5 Common mutations in lymphoid neoplasms

(bi) How does BCL-2 activation cause lymphoma? BCL-2 activation will keep cells alive by inhibiting apoptosis. Mutant cells which refuse to die are a dangerous liability. In some situations normal cells must die; one such place is the germinal centre of the lymphoid follicles found in lymph nodes and spleen ${ }^{(19,20)}$. (bii) What happens in germinal centres?

After creation in the bone-marrow virgin B-lymphocytes circulate for years in the body awaiting the first encounter with the antigen to which they have specific receptors. The meeting, should it occur, takes place in a lymph node where the captured antigen is displayed on specialised histiocytes After recognition of its specific antigen the B-lymphocyte undergoes a burst of proliferation and creates a germinal centre from its progeny.

In the germinal centre $\mathrm{BCL}-2$ expression is switched off because most of the proliferating B-lymphocytes must die. Only those with the most efficient antibody specificity are permitted to survive to become plasma cells and B memory lymphocytes ${ }^{(19)}$.

(biii) Consequence of a BCL-2 positive germinal centre If a virgin B-lymphocyte has already undergone the $14 ; 18$ translocation causing permanent activation of $\mathrm{BCL}-2$ it will probably have a long life, as usual, and no ill-effects will follow until the lymphocyte undergoes activation by specific antigen in a lymph node. The lymphocyte will then fill the germinal centre with mutant progeny and in the absence of apoptosis the process cannot be terminated. The progressive accumulation of germinal centres leads to follicular lymphoma although the process probably requires at least one further mutation.

\section{(c) Effect of other lymphoid mutations}

These can now be understood with reference to Figure 4. In mantle cell lymphoma the $11 ; 14$ translocation promotes the mitotic drive pathway by overproducing cyclin. C-myc in Burkitt's lymphoma stimulates the same pathway by an unknown mechanism. P53 inactivation will allow mutant cells into the cell cycle and effectively increase the mutation rate, by which cycle control is further degraded.

\section{CONCLUDING COMMENTS}

Parts I and II of this review have attempted to cover a substantial area of lymphocyte and cancer biology, and some concluding remarks are appropriate. Tumours of lymphocytes provide a diagnostic, therapeutic, and economic challenge. They form a stimulus for research and provide lessons for understanding cancer. Search for causes of lymphoid neoplasia is complicated by embarras de richesse. In my opinion the great majority of lymphoid neoplasms are caused by random mutations, the rate of accumulation of which increases exponentially with age due to degradation of mutation control systems. Viral infection may occasionally contribute one of the mutations required to produce acute lymphoblastic leukaemia. Hodgkin's disease and posttransplant lymphomas are probably caused by EB virus. Low doses of radiation have a powerful tumour-promoting effect in utero, but little thereafter.

\section{REFERENCES}

1 Rabbitts TH Chromosome translocations in human cancers. Nature 1994;372:143-149

2 Loeb LA, Christians FC Multiple mutations in human cancers. Mutat Res 1996;350:279-286

3 Ferguson-Smith MA Chromosome organisation, gene structure and function. Oxford Textbook of Pathology Vol 1 Eds McGee JOD et al 1992 pp69-83

4 Morris JA Spontaneous mutation rate in retinoblastoma. J Clin Pathol 1990;43:496-498 
5 Simpson AJ The natural somatic mutation frequency and human carcinogenesis. Adv Cancer Res 1997;71:209-240

6 Burch PRJ The Biology of Cancer: A New Approach Lancaster: MTP Press 1976

7 Greaves MF, Chan LC Is spontaneous mutation the major cause of acute lymphoblastic leukaemia? $\mathrm{Br} \mathrm{J}$ Haematol 1986;64:1-13

8 Kastan MB Checkpoint controls and cancer. Cancer Surveys Vol 29 Cold Spring Harbour Laboratory Press 1997

9 Jacks T, Weinberg RA Cell-cycle control and its watchman. Nature 1996;381:632-644

10 Wyllie A Apoptosis: Clues in the p53 murder mystery. Nature 1997;389:237-238

11 Nowell PC Genetic alterations in leukaemias and lymphomas: impressive progress and continuing complexity. Cancer Genet Cytogenet 1997; 94:13-19

12 Chan JKC et al A proposal for classification of lymphoid neoplasms. Histopathology 1994;25:517-536

13 Roitt I Essential Immunology 9th ed Blackwell Science 1997
14 Horsman et al Comparison of cytogenetic analysis, Southern analysis, and polymerase chain reaction for the detection of $\mathrm{t}(14 ; 18)$ in follicular lymphoma Am J Clin Pathol 1995; 103:472-478

15 Swardlow SH et al Expression of cyclin D1 protein in centrocytic/mantle cell lymphomas with and without rearrangement of the BCL-1/Cyclin D1 gene. Hum Pathol 1995;26:999-1004

16 Hoffbrand AV, Lewis SM Postgraduate Haematology 3rd ed Butterworth 1989

17 Nakamura S et al Anaplastic large cell lymphoma: a distinct molecular pathogenic entity. Am J Surg Pathol 1997;21:1420-1432

18 Ichikawa A et al Mutations of the $\mathrm{p} 53$ gene as a prognostic factor in aggressive B-cell lymphoma. N Engl J Med 1997;337:529-534

19 MacLennan I Germinal centres. Ann Rev Immunol 1994;12:117-139

20 Pezella F, Gatter K What is the value of bcl-2 protein detection for histopathologists? Histopathology 1995;26:8993 